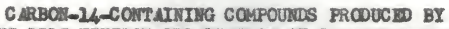
THS PILE-NEURON IRR DIATION OF CYAMOGOANDINE

by

THOMS WILLIM LAPP

B.A., Coe College, 1959

A MUTER 'S THEIS

subatted in partiel fulfiliment of the

requairements for the degree

MSTER OP SCIBACE

Departanent of Chemia try

KaNS AS STATS UIVIVSITI

Nanhattan, Kanses

1961 
TABLE OF CONTHES

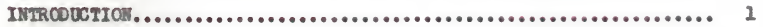

Theoretical Considerations............................ 3

Frevious $\mathrm{NL}^{1}(\mathrm{n}, \mathrm{p}) \mathrm{C} \mathrm{H}_{4}$ studies.......................... 10

EXPRRIMENTAL........................................ 21

Sample Freperation.................................... 21

Irradiation of the Cyanoguanidine Sample.................. 21

Inalysis of the Irradiated Sample....................... 23

Total Carbon-14 Activity.............................. 25

Chemical Seperations................................... 25

Radlochemical Counting Techniques....................... 31

RESULTS AND DISCUSIOW................................. 37

Distribution of the Carbon-14 Recoll Atom.................. 40

Radioearbon Froduct Distribution......................... 46

sUMART............................................. 50

ICZMONLDGMENS ................................... 51

REFRRERCES............................................ 52 


\section{INIRO UCTION}

In a Pux of thermal neutrons, nitrogen atoms undergo the nuclear trans-

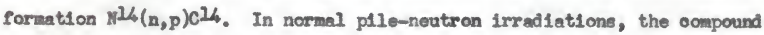
to be Irradiated is also aubjected to ganna radiation. Both the gamina radiation and the muclear reaction initiated by the neutrone are capable of supplying energ to promote chemical reactions which normally would occur only at elevated temperatures.

Collins and Calkins (6) have estimated the average energy of the gamme rays in the Oak R1dge graphito reactor to be approxdmately 1 Mev. Few nuclear reactions are initiated by the absorption of game rays at this photon energy and thus, the important muclear reactions are those produced by the neutrons.

The eyanogranidine solecule is interesting for studgling the chemical consequences produced by the nuelear transformation $124(n, p)$ cl4 for two reasons:

(1) Within the cyanoguanidine molecule, the nitrogen atoms are bound to carbon atom by three diffarent types of bonding: single, double and triple bonds. With this compound, one aight also study the effects of bonding upon the final cheniesl speciea containing the recoll earbon- $\mu_{4}$ atom.

(2) The presence of the four nitrogen atoms within the eyanoguantdine molecule perintes the production of an adequate - pecific activity within a reasonable irradiation period.

Paturally oceurring nitrogen is 99.635 per cent nitrogen- $U_{4}$ and 0.365

per cent nitrogen-15(29). The thermal neutron cross section for nitrogen-u, 
131.70 berns(17). The earbon-14, half 11 fe of 5760 years, roported by Mann, et. el. (26), has been used for celeviations in this study.

The earbon- $\mathbf{h}$, produced from nitrogen by the $(n, p)$ reaetion, reooll. wh th an average energy of about 42,000 ov. The average reeoll energ, $\bar{k}$, of the product atom when one perticle of mass, $\mathrm{m}$, is adted from the compound mueleus is gatren by(42)

$$
\overline{z_{1}}=\left(\varepsilon_{1}+Q\right)(m / M)+\varepsilon_{1}\left(m_{1} / M\right)
$$

where $\mathrm{F}_{\mathrm{I}}$ is the enerey of the inoident partielo, $Q$ is the energy releesed in the nuelear reaction, $\mathrm{m}_{1}$ in the mase of the Inotdent partiele and $M$ is the nese of the compound mucleas. The ealculations mede using the above equation are velld only when the mass of the roeoll partiele is molh ereater than the mess of the Ineideat particle. With $Q$ equal to an average value of 0.628 $\operatorname{Mer}(1,7,8)$, = equal to the mass of a proton and $M$ equal to the wass of the

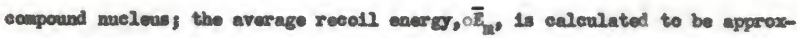
inately 42,000 ov. The 42,000 ov reeoli enerey of earbon-14 is sufflelent to break one or wore chandeal bonds present in the eyenoguanidine molecule. For cxample, the earbon-nitrogen triple bond is the strongest hond between the two elements and has an energ of 8.4 ev(13).

Inmediately after aequiring this eneres, the recoll atom moves through the edjacent surroundinge at a high velocity. This enerer is dissipated by collision with other moleoules and when the energy of the reooll aton is sufflelently redued it mey enter into chemical recombinations or other resetions. 


\section{Theoretieal Considerations}

Varlous theories have been advanced in attenpts to explain the proeesses occurring during the period imediately after the reooll atom has broken all It bonde and becomes mobile, to the point of incorporation of the recoll atom Into some ultinate chenical specie.

Two of the thoorles advaneed were proposed to rationalise the flelds obeerved in the condensed phase in $(n, \gamma)$ studies of alkyl halldes; however, they have boen extended to other aystoms as well. These two theorles are the "billiand ball collision-ept thermal collision" theory, proposed by Libby $(20,21)$ and the "randon fragmentation", or "nest of radicals" theory, proposed by w11 1 ard $(45)$.

The billard ball-collision theory, advanced by Libby (20), postulates that the recoll atoms in the Iiguld or solld aedium lose their energy by mementum transfer in elastic collisions with single atoms. This assunes that the tranefer cecurs in the aane manner as if the atom were 1solated atom In the gaseous phese. A head-on collision of the recolling atom with another atom, of approximately the same mess, would reault in nearly a 50 per cent energy transfer to the struck atom, thus projecting it into the medium. These atom, in turn, transfer energy to other atoms or molecules within the medium to melt a pear-ahaped region in the solid with a volume of the order of $10^{3}$ molecules. The recoll atom would renaln in the solvent eage with the radical Froduced as result of the collision and so would have a high probability of combining with the radical to form a able chendeal species. If the recoll aton had struek the atom at a different angle, a glancing collision rather than a hesd-on collision wovld have cceurred and the enerigy transfer 
would not have been as complete. In this case, the recoll atom might escape rrom the solvent eage without nedergoing recombination with the radieal produced.

A head-on collision of the carbon-14 recoll atom with hydrogen atom would have resulted in the lass of about 25 per cent of the energy of the reooll atom and the recoll atow would retain nearly 75 per cent of the oner $6 y$ previous to the collision. Therefore, the recoll atom would not be expected to stey in the solvent eage with the radicel formed by the bond breakage.

The billiard bell theory predicts that all of the reeoll atome would enter combination such that the parent compound is re-formed. The results of numerous investigation heve shown that the final chemical state of the recoil atom is not entirely that of the parent compound. Libby(21) suggested that this wight be expleined by assuming that when the onergy of the recoll atom was redueed to approxdmately 10 ev by succesalve collisions wh th other atoms, a new type of energy transfer would become possible. In the range of $\mathrm{g}<10 \mathrm{ev}$, but not in the higher energy reglons, the recoil ato may transfer energy to molecules as a whole by inelastic collisions, wh the subsequent breakage of one of the bonds of the molecule resulting from vibrational exeltation. If, for exauple, hydrogen bond were ruptured in an inelastie collision, the recoll atom would ramain in the solvent cage with the radical formed and thus would have a high probability to substitute for the hydrogen atom In forming stable chemical spec1e. These types of reactions have been termed "epithermal" In contrast to those occurring at the h1gher onerglea.

Willard (45) postulated the "random fragmentation" theory, in which, 
the reooll atom in a liquid or solid phase acquires a recoll energy of aeveral hundred electron volts and starts to move rapidy through the medium. When the recoll atom has traveled 2 ess than anoleculer dianeter, it encountars a solvent molecule. If this were an isolated nolecule, as in Libby's theory, the energetic recoll atom would transfer part of its energy to the molecule or to one of 1 ts atoms and continue through the aediua. In the 11quid or solid phase, this cannot happen since the struck molecule is surrounded by a cloely packed and sometimes intertwined wall of other solvent molecuies. The result is that the energ is dissipated by an indiscrininate rupture of bonds in the invediate vieinity of the energetic recoll atom. When the energy of the recoll atom has been reduced below the energy required to rupture bonds, the carbon-14 recoll atom will be located in, or adjacent to, a pocket containing a high concentration of radicals and atons. The recolI atom nay combine with one of the radieals after the energy of the recoll aton has been reduced where combination is possible, but before 1 t has had an opportunity to diffuse Into the medium a thernal atom. In alternate mechanism Is that it may enter stable combination by a thermal process, after diffusion in thermal eguilibelum with the medium. In systens where the activation energy for the various reactions of the recoll atca with the solvent is high, the thermal atom nearly always combines with a radical or $10 n$ which it produced during the dissipation of 1 ts recoll energy. These radicals or lons are encountared by the recoll carbon- $U_{4}$ atom after collisions with the solvent molecules.

The relative muber and the specific typea of fragnents formed by the recoll atom depends on the chentcal nature, structure, and density of the mediu and on the mass and energy of the recoil atom. It way also depend upon 
the activation energies for 1 ts reactions with the other malecules of the medium.

Recently Harbottle and Sutin(14) have applied the "displecenent spike" concept, proposed by Seitz and Koohler(36), to construet a model for nuclear transformations in sollds, and to consider how the recoll atom disposes of Its high onergy and the various processes in returning it to stable chemionl combination.

The "displacement spike" theory distinguishes between two energy regions. (1) The hot region in which all reactions occur before the recoll atom reaches therael equilibriom with 1to onvironent. This region includes all onergica above 0.025 or; (2) The thermal regions in which the recoll atom is able to diffuse through the environment and undergo the more fandilar chemical reections as recombination, exchange, addition and substitution.

Reactions occurring in the hot region me of two general types: (a) reactions proceeding by the direct roplacement of an atoil within a molecule by the recoil atom; (2) chenifeal reactions similar to those which oceur in the therwal region but which are modified by the local higher temperatures.

Immediately after the formation of the recoil atom, the aton may lose energy by electronic exeitation or by lonisation during the slowing-down process. For recoll onergles less than $20 \mathrm{kev}$, in all cases of chemicel interest, the recoll aton will not lose electrons or 1anlse the surrounding atoms. In sono cases, the recoil atom nay be positively eharged at the beginning of the path. However, at the end of 1 te travels, It will be in that oxddation state In which the removal of en electron from the lattice requires more energ then that powsensed by the recoll atom. It is also necessary to consider the environnent 
of the recoll atom in addition to the various energiee possessed by the recoil atom during the slowing-down process. The binding forees in lonie eryatels are atronger than those in molecular crgatals so that onvironmental factors In 1onie crystals will be more important in deternining the probability of electron transfor than in molecular crystals. The initial chemical state of the recoll atom is also of importanee in eonsidering the probability of eleetron transfor. In lonic crystals, if the recolling atom is infilally in a high chemieal oxddation stato, the probability of eleotron transfer to the mediun will be leas then if the atom had initially been in a lower oxddation state. In molecular erystels, where intramolecular bonding is predoninately covalent, the recoll atom probably starts out, and remalns to the end of its range, neutral atom.

The primary atom, or recoll atcom, dissipates approxdmately half of its energy by produeing secondary atoms through displacement reactions and the remainder is lost in excitation of lattice vibrations. For typical recoll onergies of approximately $300 \mathrm{ev}$, the recolling atom produces about 6 atomile displacements in the slowing-down process in lonic erystals and, because of the weaker intermolecular binding, the reeoll atom will produce about 16 atomie displacements in molecular erystals. Due to the higher recoll energ, the carbon-14 recoll atcan would produce a larger number of atomile displacements. These lonic and molecular exystals normelly contain several kind of atom of different massos and different oxddation states such that collisions between atom of different messee must also be considered. The maximum energy which the recoil atom can transfer to an atom of different mass in collision is given by 


$$
\varepsilon_{n}=\frac{4 M_{1} n_{2}}{\left(x_{1}+n_{2}\right)^{2}} B_{1}
$$

where $K_{1}$ and $y_{2}$ are the sass of the reoolliag and struck atom, and $z_{2}$ is the energy of the recoll atom before the collis 10n. The recoll atom vill undergo wore collisions in the sloulng-down process in a medina where ito mass is different than that of the gurrounding atons since the maxiun onercy tranafer in a collision cecurs between two atom of the same sass.

Reaction in which the recoll atom efects a bound atoa and takes its place have been terned "roplaeenent or Interchange collialon" and are of conaldarable Importance in chenical syetens. A suceessfal interchange colligion can occur wherever the energy transferred to the struek etom by the recoll aton 18 greater than the energe required to displaee the aton to an Interstitlal position and the energy of the reeoll atom 1 deereased to lese than that required to displace the struck aton vithin the sane collision. Since the cage enere is higher in solids than in 11quids, due to the stronger Intermoleoular forces and greater density, conditions are nore favorable for a reconblnation reaction in solids than in 11 quids. Roeombination reactions are more probably in 1ontc cryatals than in molecular erystals for molecules of oonparable conplexty and bond strength.

If one assumes that only alsstle collislons oceur and the carbon-14 recoll aton lesea on the average epproxdmately soven-tenth of 1 is eneres In each elastle collision with an atom of the cyanoguantdine molecule, a ralatively small number of coll1s1ons (approxingtely 7) will be required to reduce 1 ts energy belou $10 \mathrm{eV}$, where the recoll atom may begln to becone stable toverd chenlesl recombination. The total tine required for this soudig-down process is of the order of 10-13 see. and the mean free path 
of the atom is about $5 r$, where $r$ is the atomic radius (14). This abrupt loes of wost of the energy within a small volume will produce very bigh local "tenperature". These small volunes of hlgh "temperature" are termed "hot-spots". The recoll atom 18 therwallzed in a series of about 5 to 10 hot-spots which 11. within a radius of about 10r. These local hot-spots morge within a tive of about $10^{-12} \mathrm{sec}$. to form a hot zone or "displacement splke". The hot zone In an Ionic crystal lattice involves volume of the order of $10^{3}-104$ molecules and reasins at a temperature above the melting polnt for approximately $10^{-11}$ sec. Sinilar considerations indieate that an equal amount of energy dissipated in a molecular crystal lattice with a lower melting point, will welt a volume approximately four times gs great as that for an ionic lattice. Dne to the smaller thermal conductance in molecular sollds, the hot zone will remaln above the melting temperature for a longer period of the than that in an lonle crystal lattice. Since liquids are generally better thermal conductors than sollds, the I1fe-tine of the "displacement splke" In solids will be longer than in 11quids. The heat factor and the larger enge energies will increase the number of reactions in the hot zone when a compound is Irrediated in the sol1d phase rathor than in the 11 quid phase. In view of the high temperatures Froduced in the hot sone, additional fragments may exist due to the therael dissociation of molecular crystals.

W1thin the hot zone, there is a good chance that the recoll fragmente will react with one of the species in its imediate vicinity provided the energy of activation is not too high. The neighbors of the recoll fragments w11l be parent molecules, if a pure compound is irradiated. This favors the roaction of the recoll fragment with the parent species and the products corresponding to this reaction 111 be produced in addition to products resulting from the 
recombination of the recoll fragment with a collision fragment.

$$
\text { Previous } \mathrm{H}^{14}(\mathrm{n}, \mathrm{p}) \mathrm{c}^{14} \text { studies }
$$

The first reported analyals for the chemical species containing the recoll carbon-14 aton, produeed by thermal neutron irradiation of nitrogencontalning organle or Inorganic compounds, was by Yankwleh, Rollefa on and Morris (58). Crystalline amonium nitrate, urea, hydrazinium chloride and glycine vere 1rrediated with thermal neutrons. Aqueous solutions of amentum nitrate, urea, and pyridine and pure aniline were also aubjected to Irradlation with neutrons. Following the irradiation, the samples were disoolved in water and analyzed for various compounds, containing one carbon atom, such as carbon dioxdde, methane, formaldehyde and methylamine. Carbon dioxide and carbon monoxdde vare found to contain over $90 \%$ of the total isolated activity in aqueous and crystalline ammonium nitrate samples. Hydrogen cyanide was observed to contain $55 \%$ and $71 \%$ of the total isolated carbon-14 activity in crystalline urea and hydrazinium chloride, respectively. Approxdmately $50 \%$ of the activity isolated from the irradiated eryatalline glyeine was present in the form of mothanol. Inconclus Ive results were obtalned from the Irradiation of aqueous pyridine and pure anlline. Yankwich, et, al. concluded fron thelr results that carbon dioxdde and carbon monoxide are the predominate opecies containing the rocoll carbon-14 atom in those compounds which contained oxygen within the molecule and that carbon dioxdde tends to be formed In greater abundance than carbon monoxdde. Methane-cl4 appeared onily in the absence of oxggen in the molecule and in the presence of a high hydrogen dens1ty. Hydrogen cyanide, containing the recoll carbon-14, was found to coeur only in the absence of a high oxygen concentration, while mothanol and formic 
weld tended to appear only in the presence of vater.

Giacomello and Zifferero(11) Irradiated crystalline amonium oxalate with thermal neutrons and dissolved their sample in water before analyzing for the varlous chemical species contalning the recoil earbon-14 atoin. Approximately 11\% of the total activity produced was found in oxalic acld, with gmaller anounte in carbon monoxdde, carbon dioxdde and hydrogen cyanide. The chenieal form of the remainder of the total aotivity produced, $77 \%$, was not deternined.

Iankwleh(5/4) Irrediated solld beryllium nitride with thermal neutrons and, upon dissolution of the sample in water, determined that $63 \%$ of the total activity produced wes in the form of methane. Smeller anounts vere present as carbon monoxdde, carbon dioxdde and hydrogen cyanide. An oxidisable fraction, primarily formic ac1d, was found to contain $27 \%$ of the total carbon-14 activity. Iater, Iankulch and Cornman(57) Irradiated solid beryllium nitride again and an analysis of the Irradiated compound gave $26 \%$ of the Induced total activity as methane. Guanddine, methylhydrazine and carbon dioxde were found to contein 19\%, $11 \%$ and $14 \%$, respectively, of the total activity produced during the nentron irradiation. The latter results diffor quite significantly rrom those previously obtained. The difference between the two results was attributed primarily to an incoaplete analysis of the former beryllium nitride sample. Iankuich and Cornman concluded that the appearance of nitrogenous compounds among the final products was evidence that the skeletons of complex chenteal apecles are formed and remain stable in the irradiated crystals.

Barbier1, ot. al.(2) subjected solld phenylalanine to thermal neutron Irradiation. The solid was dissolved in water, following the irradiation. 
These Investigators analysed for 23 different chenical species that may have contained the recoil carbon-14 atom. The separation of many of the products was accomplished by paper and column ehromatographic techniques. Ispartic acid, formie acid and glutaric acid were found to contaln $5 \%, 4 \%$ and $4 \%$, respectively, of the totel Induced carbon-14, activity. The renainder of the 1solated activity, was found in small amounts in the romaining compounds. The authors were unable to account for $64 \%$ of the totel induced carbon-14 activity. The signifieance of the result obtalned was not discussed since only about one-thind of the activity was detarnined.

Iankwich and Vaughan(59) found that $80 \%$ of the activity produced by the neutron 1rradiation of solid amoniun brandde was present as mothylantine. Pollowing irrad1ation, the target sawple was dissolved in water, and analysed for the various chendeal spocies. Snall amounts of activity were also found in the form of wethane, formaldehyde and carbon dioxdde. The results vere discussed in terme of natrix-stablilsed species which, upon addition to vater, Interact with the olvent to produce chemically stable products. The high yleld of wethylamine was interpreted as evidence for the high stability of the C-H Iinkages within the matrix of the Irradiated erystals.

Bellueo, et. al.(3) studied the varlous chemleal speeles produced by the neutron Irradiation of solld amsonine nicotinate. Inalysis of the Irradiated compound, after dissolution in vater, showed that $16 \%$ of the total carbon-14 aetivity was introduced Into malonic acid, with lesser amounts of the activity in compounds such as nicotinic actd, butyric acid, bensoic ac1d, and carbon dioxdde. They were able to account for only 325 of the totel activity induced in the sample by the neutron irradiation. 
Cacace and comorkers (4) subjected solid benzanilide to analysis for the various chemical species produced by the neutron 1rradiation of the solld sample. Opon dissolution of the target material in vater, carbon monoxdde was found to contaln $12 \%$ of the total Induced aetivity. Carbon dioxdde, hydrogen cyanide and bensanilide were found to conteln smaller amounts of activity, while mothylamine, farnalidehyde, formile acid and bensene were found to be essentially free of any induced activity. The total 1solated activity accounted for only $22 \%$ of the totel induoed carbon-14 activity.

Zifferero(63) and Gaconello(10) Independently studied the ohemioal species reaulting from the Irradiation of erystelline quinoline oxalate. In each study, naphthalene and oxalle acid wore found to contain the greatest amount of activity with smeller amounts present in the form of quinoline, d-naphthol and carbon dioxde. The 1solated netivity secounted for only apgroxdately one-sifth of the total carbon-14 activity in eech of the studies. Conclusions based on the reeults obtained in the studies vere not presented. Gacomallo(9) found that beasene conteined $8 x$ of the total induced activity obtained by irradiation of pyridine oxalate in the solid state. Phenol, carbon dioxdde and carbon monoxdde were found to contein lesser amounts of the Induced activity. The 1solated activity accounted for only $15 \%$ of the total Induced activity in the solid terget material.

Crystalline $\mathrm{M}(\mathrm{CH})_{2} \mathrm{HH}_{3} \mathrm{C}_{6} \mathrm{H}_{6}$ was irrediated with therwal neutrons by z1fferero(61). Inalysis of the target material, after dissolution in vater, showed activity present in the form of oxalle acid, bensene and hydrogen cyanide, with trace amounte present in carbon monoxdde and carbon dioxide.

Yenkwleh and Corman(56) determined the cherilcally 1solatable species 
resulting from the neutron 1rradiation of erystalline ammonium sulfate. Dissolution of the target material in water showed that 40 per cent of the totel setivity was in the farm of carbon dioxdde. Methylamine, farmic acid and formald ehyde were isolated from the aqueous solution of the Irradiated anonim sulfate and were found to contein 16\%, 16\% and 13\%, respectively, of the total activity produced in the sample. Lesser anounts of activity vere present in hydrogen eyanide and wrea. The results indicatod that possibly many of the radicoarbon compounds were produced In the erystalline matrix and trapped in the matrix under strain of the solid. It was also suggested that the activity nay possibly result from reactions with the solvent of earboneontaining opecies trapped in the orystalline lattice.

Crystalline hydrazine oxalate was irrediated with neutrons by Zifferero and Cier1(62). Analysis of the terget material, dissolved in water, showed that formic aeld, oxalic acid and methylamine conteined 13\%, $11 \%$ and $10 \%$, reapectively, of the total activity produced during the neutron irradiation. Lesser amounta of aetivity vere present in carbon dioxido, formeldehyde and carbon monoxdde. Crystalline naphthalene was added to the sumple prior to Irradiation in an effort to label the naphthalene by the recolling earbon-14 atom. The results showed no moasurable amounta of activity present in the naphthalene after 1rradiation. Inalysis of the 1solatable species resulting from the Irradiation accounted for only $48 \%$ of the total induced activity. These results, together with some of the results mentioned previously, emphasize the fact that in the larger and more complex nftrogen-eontaining molecules not all of the indueed sotivity is present in chenical species which can be reedily isolated from the system.

The use of the recoil carbon-14 atom produced in the irradiation of 
nitrogen-containing compounds have been Investigated at tool for the synthesis of compounds Incorporating the recoll earbon atom. In these Investigations, only the partioular products of Interest vere isolated from the mixture.

The neutron Irradiation of crystalline acotanide was carried out by Wolf, ot. 2. (50). Their appronch centered on the re-entry product, acetanide, and the synthesis product, propionamide. Acidic and besic hydrolysis of the anddes to the acids wes carried out to determine the possible differences in state of the irradiated anterial. Analyeis of the Irradiated sample showed acetic acid eontained $8 \%$ of the total setivity while propionie acid conteined $5 \%$ of the total Induced activity. The results were discussed in terms of propesed mechanisus for the formation of the re-antry and synthesis product. Degredation studie were ourried out on the products obtained by the Irradiation and the setivity present at each position wes deternined.

Zifferero(60) earried out the neutron Irradiation on a serles of eryatalIine organio oxalates. The target samples were anp?yzed to determine the activity present in oxcilic acid and in the free organic bese. The analysis showed oxalic acid to contain 2\%, 1\%, 1.5\%, 3\% and $4 \%$ of the total indueed aetivity in the oxalates of pyridine, quinoline, laoquinoline, aniline and I-methylaniline, respectively. The free beses were found to contain $2 \pi, 2 \pi$, $10 \%, 8 \%$ and $11 \%$, respectively, of the total indueed activity.

Wolf and coworkers $(48,49,53)$ have 1rrediated a series of erystalline organic compounds and anslyzed the target materials for the incorporation of the carbon-14 reeoll atom in specific chemical species. Bensene and toluene, 1solated from sn irradiated smaple of 2-methylpysesine, containing amell anount of bensene, wore found to contrin $1.9 \%$ and $1.0 \%$, respectively, of the 
total Induced setivity. Aeetic acid and proplonic acid vere isalated from an Irradiated sample of acetanide by acidie and basic hydrolysis of the target ateriel. The acetic acid was found to contain $6.5 \%$ of the totel activity by basie hydrolysis and $8.1 \%$ of the activity by acidic hydrolysis. Froplonic acid contained $6.7 \%$ and 5.03 of the total indueed activity by besic and acidic hydrolysis, reapectively. In analysis of Irradiated acridine showed that $3.5 \%$ of the total Induced activity was present in the parent compound and $0: 2 \%$ of the totel activity was present in naphthalene. Gased evalved from the sample vere found to contaln $3 \%$ of the total activity w th the remaining activity present in the form of a polymaric naterial. Solid solutions of asobensene and stilbene, contalning varying anounts of asobensene in the stilbene, were analysed for the activity present in the fari of et1lbene, asobensene and benselaniline. The reaults showed that a the mole frection of asobensene Increased, the per cent of the total ectivity as asobensene increased and the per cent as at1lbene decreased. Heasurable anounts of activity were found in bensalaniline at only 10 and 7.5 mole per cent asobensene. The result also showed that by a comparasion of the activities found in the bonsene rings of the two canponente in the agsten, the ring activity ylold of stlibene and sobensene vere nearly equal when comparing pure asobensene to an extrapalated value for st1lbene. The authors concluded that the ring entry is apperently not effected by the nature of the exceyelle structure.

Naxart(27) Irrediated erystalline 5,6-bensacridine with neutrons and anelyzed the target anterial for the setivity present in the form of 5,6

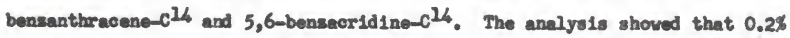
and $4.0 \%$ of the total Induced activity was present as 5,6-bentanthracene and 
5,6-benzacridine, respectively.

The Irrediation of crystalline bensamide and bensenesulfonewide vith thermal neutrons was cerried out by Cacace, ot. al. (5). The Irradiated bensamide was analysed for the activity incorporated in aniline, bensamide and bensoic acid. The anelysis showed that $4.2 \%, 3.3 \%$ and 1 ess then $0.1 \%$ of the total Induced activity was present in the isolated bensamide, aniline and bensole acid, respectively. The Irrediated benseneavifonamide was analyzed for the aetivity preeent in phonol, bensamide and bensole acid. The results of the analysis shoved that $4.2 \%, 1.5 \%$ and $0.9 \%$, reapectively, of the total Induced ectivity was prosent in the three samples. Mechanisus vare given for the reations leading to the final incorporation of the reooll carbon-l/ atom In ach of the isolated species.

Norris and Snell(30) 1nvestigated the large acale pile produetion of $\mathrm{c}^{\mathrm{L}}$ by thermal neutron Irradiation of aqueous solutions of anmoniun nitrate. They found that the greatest majority of the Cll was liberated an carbon dioxdde and carbon monoxdde. The carbon dioxide-cll and carbon monoxdde-clit, after conversion of the earbon monoxdde to carbon dioxdde, was precipitated warium carbonate.

The labeling of organie molecules euploying an external nitrogencontaining coapound as the source of the recoll earbon-14 atom has been roported by severel authors. Professor W. F. Libby has been the major contributor to these labeling studies and the majority of the results reported in the IIterature are due to his investigations.

Mbby and MaeKar $(22,23)$ Irradiated solutions of n-pentane and 1sopentane 
with therral neutrons. Small amounts of anillne were added to each sample prior to irrsdiation to serve as the source of nitrogen. The chenicel apecies produced by the neutron irradiation were seperated from the solution by rracthonel distillation. Anelysis of the low bolling hydrocarbons shoved that p-hexane, 3-methylpentane and p-heptane contained 12\%, 8\% and 6\%, respectively, of the total activity induced into the n-pentane sample. 3-mothylpentane, 2-methylpentane and 2,2-dimethylbutane were found to contaln $9 \%, 7 \%$ and $6 \%$, respectively, of the total sctivity induced Into the isopentene semple. The remainder of the activity 1solated from the lower bolling hydrocerbons was found in mang of the hydrocarbons from butane to hexane. The higher boiling hydrocarbons were anelyzed by selecting two hydrocarbons which vould produce a bolling range of from ton to sixty degrees. The activities isolated in these rractions were not analysed to determine the specific ohemical species. A polymeric ateriel was found to contain $26 \%$ and $28 \%$ of the total activity of n-pentene and isopentane, respectively.

Solutions of earbon tetrachloride, containing small amounts of aniline and pyridine, were Irradiated with thermal neutrons by Hein, et. al. (15). Analysis of the irradiated samples showed that about 31 per cent of the total activity induced into the samples was found in the earbon tetrachloride.

Libby and Sehrodt(24) Irradiated a series of nitrogen-oontaining compounds and nitrogen compounds dissolved in various solvents. In the analysis of Irrediated aniline, 23\% of the total Induced activity was isolated In fourteen different chemical species resulting from the 1rradiation. The analysis of the Irradiated $8 \%$ aniline in bensene sample showed that 62.5 par cent of the total activity remalned in the bensene layer after acid extraction. Anelysis 
of the chemical species present in the benzene layer accounted for 9.5 per cent of the activity observed in the laver. Isolation of the chemical speciea resulting from the 1rradiation of $10 \%$ aniline in methenol accounted for essentielly 100 per cent of the totel Induced activity. Mothane, methanol and p-propanol contained $34 x, 16 \%$ and $9 \%$, respectively, of the total activity. The remainder of the activity was present in the higher alcohols and a basic fraction. The bensene layer resulting from the analysis of the Irradiated triphenylamine contalned 69 per cent of the total activity. The chemical species present in the benzene layer were not 1solated. A sample of aniline hydrofluoride was 1rradiated with neutrons and the analysis of the target materlal showed that $32 \%$ of the total activity was extracted into 0.211 hydrochloric acid layer. The chenical species present in the extract were not Identified. Ethylasine, ethylamine hydrofuoride and methylamine hydrofluoride were also 1rradiated with neutrons. In the analysis of the terget materials essentielly 100 per cont of the total induced activity wee isolated. Various amines were found to contaln essentially all of the activity produced in eaoh of the three samples.

Wolf and Iang(52) have conducted ges phase 1rradistions of pure anhydrous amonila and ammonia-inert gas mixtures with thermal neutrons. Mixtures of amonis with oxggen and methene and pure methylamine were also 1rradiated. Nothane was found to contain $94 \%$ of the total induced activity in pure amanis and over $90 \%$ of the total Induced setivity in the mixtures of amnonla with neon, xenon and oxygen. Analysis of the armonia-nethane mixture showed that $60 \%$ of the activity was present as methene and $34 \%$ of the ectivity as a polymer. The irrediation of pure methylamine produced 10-20 per cent of the total Induced activity in polymer. The chemical apecies containing the 
semainder of the activity were not 1dentified. The authors coneluded from these results that a hydrogen transfer oecurs during the lindted but finite lifetime of an intermediate formed by an elastic collision between the oarbon fragment and the hydrogen source.

Wolf(46) discussed the use of the recolling carbon-14 atcom as achnique for labeling organic compounds. The percentages of incorporation of

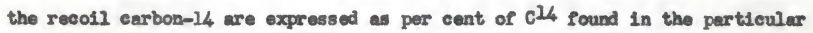
compound relative to the total amount of cll produced during the irradiation. The chemfeal offects of the nuelear trensformation $114(n, p) c^{24}$ has been discussed in detall by Yankwich(55). Resulte obtained by lankwich and comoskers are interpreted in terms of the Libby hard-aphere model and the Seltz-Koohler model. Comparisons between the distribution of the radiocarbon products and the oxddation state of the carbon atom is made.

Freellent review articles coneerning the 1sotopic labeling of organic compounds through pertion Irradiation and the chemical effects of the nuclear transformation have been given by Wolf(47) and Muxart(28). 
EXPERTMAITAL.

The experimental procedure used to study the ohenical changes produced in eyanoguanidine by thermal neutron irradiation will be discussed in the following order: preperation of the eyanoguanidine for Irradiation; plleneutron Irradiation of the anples, and the ohenicel and radiochenicel andIyels of the irradiated cyanoguanidine.

\section{Sample Preparation}

Cyanoguanidine, Bastman Red Label, was recrystallised twice from distilled water and frred in an electric oven at $100^{\circ} \mathrm{C}$ for one hour. $4.952 \mathrm{gm}$. of the dry, purifled eyanoguanidine $\left(M_{0} P_{*}=205^{\circ} \mathrm{C}\right)$ was placed in a 8 on 2 an diamoter quarts ampoule. Prior to filling the anpoule wth the purifled compound, the quarts ampoule was trented with chromic acld, washed and dried thowoughy in an electric oven. After filling the ampoule vith the purified eyanoguanidine, the ampoule and contents were attached to the vacurum Ine Wth quarts $10 / 30$ standard taper joint in a vertical position. Gare was taken to remove all traces of oxygen and water vapor from the sample. Th1s was accowplished by alternately evacuating and Plushing the systen several times with argon. After flushing the system several times with argon, the amporile and contents were evacuated to a pressure below one mieron; the quarts ampoules were then sealed off using a hand torch.

\section{Irrediation of the Cyanoguanidine Semple}

Irradiation of the eyanoguanidine was carried out at Oak Ridge National Laboratories in the ORKL graphite reactor. At the location in the graphite reactor where the irradiation was made, the neutron flux was stated to be 
approximataly $5 \times 10^{11} \mathrm{~cm}^{-2}$ see ${ }^{-1}$, with an accompanylng gammaray flux of $4.9 \times 10^{5} \times \mathrm{hr}^{-1}$. The sample was irradiated for 28 days at the smbient pile temperature (less than $80^{\circ} \mathrm{C}$.). Upon conplettion of the Irradiation, the sample was returned to our leboratories. The semple was stored for 15 month before the axpoule was opened and the analyaes made.

The enount of deconposition produced in the cyanoguanidine by the gannaray Slux present during the pile-neutron irradiation was eatimated in the following manner. One roentgen is equivalent to the abocrption of approxdmately 100 ergs per grem of ater1al. A G value of 41 is essumed, (40) where the term $G$ value is the number of molecules decompesed by the absorption of 100 ev of energ. Since the gamalray flux was epproxdmately $5 \times 10^{5} \mathrm{r} \mathrm{hr}^{-1}$ for this irradiation, the energy absorbed by the sample is calculated to be $5 \times 10^{7} \mathrm{ergs} / \mathrm{gm} / \mathrm{hr}$. The total irradiation time was approxdmately 670 hours and, thus, the total energy absorbed by the aample was $3.4 \times 10^{10}$ orge/gm, or $1.7 \times 10^{11}$ args for the 5 gm sample. Converting ergs to electron volts, a velue of $1.1 \times 10^{23}$ ev was obtained as the total encrgy absorbed by the sample. Multiplying the total energy absorbed the sample by the $G$ value and the reciprocel of Avagadro's number, decomposition of $7 \times 10^{-3}$ moles was obtalned. Multiplication of the number of moles deccuposed by the reofprocal of the number of woles of sample Indicates that apperoxinately $12 \%$ of the sample was damaged by the gama-rays during the 1rradiation period, if the assumed valve of $G$ (eyanoguanidine $)=4$ is valid.

The chemical effects produced by the rather extensive decomposition of the sanple by the gansa-rays was not investigated in this study, since the primary interest wes in the stable chemical species incarporating the recoll carbon-14 atom. 


\section{Analysis of the Irrediated Sample}

The quarts ampoule containing the 1rradiated eyanoguanidine ves opened under vacuum by moans of the apparatus shown in Figure 1. The ampoule was placed in the brase eylinder and the port to the eylinder was elosed and sealed with Apieson-"W" to give a vacuum tight elosure. The entire system was evacuated to a pressure of less than one mieron and the stopeock was then closed off from the system. The brasa eylinder was removed from the vacuum manifold and shaken until the ampoule was broken by impect on the projoeting sherpened machine-serew. The cylinder was reconnected to the vecuum ilne and oracuated to the atopeock. The gasee evolved upon breakage of the quarts ampoule were then allowed to expend Into an auxdliery vacuum system and collected. The irradiated compound and plecee of the broken quarts ampoule were transferred, under an argon taosphere, to a stoppered pyrex weighing bottle. The sample was maintained under an argon atmosphere during the entire course of the experimental atudy.

The total carbon-14 activity of the Irradiated sample was determined by the dissolution of aceurately welghed portions of the aample in distilled water using volumetric glassware. Aliquots were taken and the total activity determined using Ilquid aeintillation counting techniques.

In arder to eatabliah the distribution of the carbon-14 activity among the apecies likely to result upon disaolution of the irradiated samplen in water, the samples were dissolved in distilled vater contained in an inverted I-tube connected to the vacuras aystem; the solutions were then aubjected to analyses for the various spectes present.

A small sample (50-100 mg) of the Irrediated eyanoguenidine was placed 


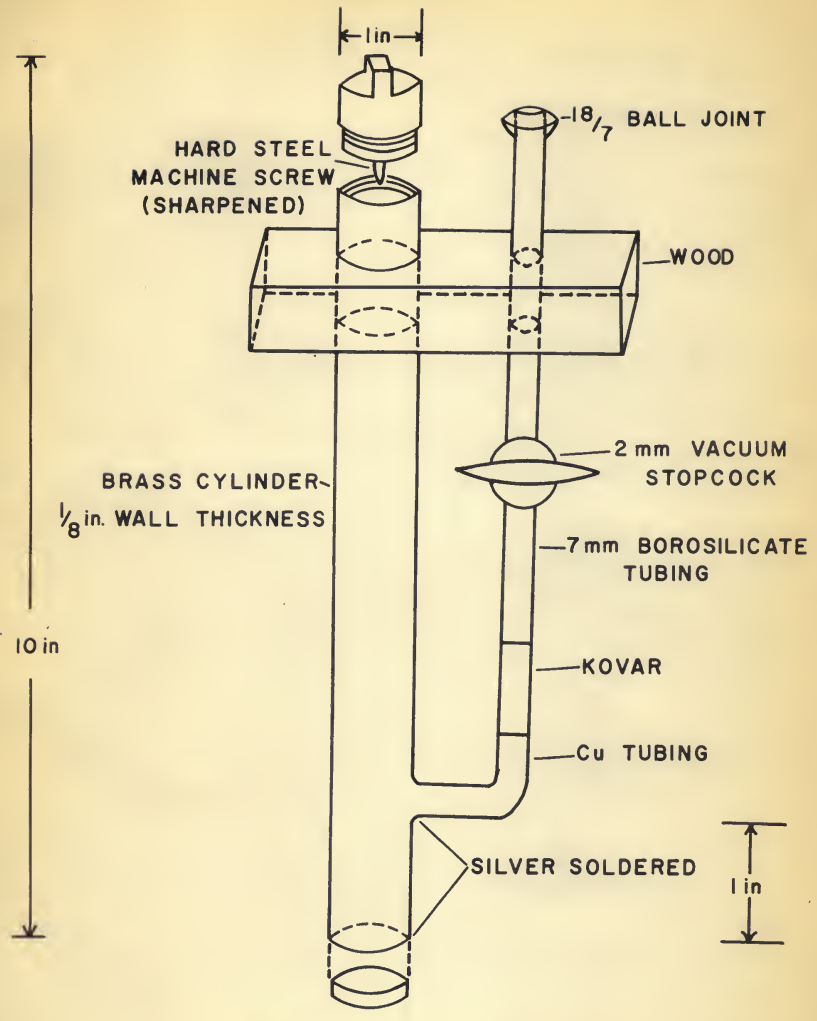

FIGURE I ILLUSTRATION OF SAMPLE OPENER 
In one arm of the inverted I-tube and distilled water (approxdmately 5-20 ml) was pleced in the other arm. The I-tube was connected to the vecurim Iine and the water degassed by alternately freesing with liquid air and warning while under vacuvin. The auxdliary system was fitted with a cold trap, $250 \mathrm{ml}$ bulb for collecting the evolved gases and a mereury manometer. The ontire syutem could be evacusted and elosed off from the main manifold of the vecurim system. The I-tube was elosed off from the innediate system and the lee wes allowed to melt. The water was added slowly in stope to the dry sample while alternately opening the I-tube to the evacuated system. Upon addition of all of the water to the sermple, the pressure change was recorded with the menometer and the collection bulb wes closed off. The gaseous contents of the collection bulb were anelyzed for carbon-L/4 containing chenical specles evolved by dissolution of the sasple in water.

\section{Total Carbon-14 letivity}

The total activity produced in the 4.952 gin sample of eyanogranidine was determined to be $18.6 \pm 0.7$ mierocurles. This is an average value obtained from four different deterninations on different samples made over a period of four months. The error quoted is one standard deviation.

\section{Chemical Separations}

The prineiple problem eneountered in the analysis was the quantitative separation of the various activities free from contamination. Therefore, all components and derivatives isolated wore purifled to constant specifle activity to achieve radiochemical purity.

Carbon D10xdde. Carbon dioxdde vas determined by direct adsorption on 
sodiun hydroxdde or caroxdte. The carbon dioxdde evolved during the addition of water to the sample was removed by the insertion of a trap, containing elther sodium hydroxide or caroxdte (5-20 mesh), Into the system between the I-tube and the gas collection bulb. The sodiun hydroxdde or earordte was subequently dissolved in distilled water and a known allquot removed to determine the radiccarbon activity.

Garbon Monoxdde. Carbon monoxide evolved upon sample dissolution was subjected to gas ehromatographic radioanalysis using linde molecular wleve 54 as column packing. Radioanalyee were made by passing the efRuent from the colum directly through a proportional counter, after wixing with an argon-methane mixture.

Hydrogen Cranide. Direet edsorption on sodium hydroxide was used to collect hydrogen eyanide, in a manner similar to that deseribed above for carbon dioxdde. The hydrogen eyanide was evolved by the addition of a $50 \%$ aqueous sulfuric acid solution to a sample of the cyanoguanidine contained In the Y-tube.

Yethans. Gas ehromatographic radioanalys is was also used for the methane evolved upon sample dissolution; the procedure was the same as that employed for carbon monoxdde.

Formaldehrde. To an allquot of a degassed solution of the 1rrediated sample conteining carrier formaldehyde was added a solution of Mathone (dimedion) in $95 \%$ ethanol. The solution was alloved to stand for 22 hours at room temperature. The precipltate formed was filtered, repeatedly reerystalIIxed from a $50 \%$ othanol-water mixture to a constant specifle activity, and dried at $115^{\circ} \mathrm{C}$ for 20 minutes $(16,44)$. A veighed portion of the derivative 
was dissolved direotily in the seintillator solution and counted.

Bosmic deld. Ten ml. of $1.0 \mathrm{~K}$ acetic acid and $50.0 \mathrm{ml}$ of a solution, prepared by dissolving 100 gms of mereuric acetate in 111 ter of $0.5 \mathrm{M}$ acetic acid, were added to an allquot of the degassed aample after addition of camier formic acid. The solution was brought to reflux, and the carbon dioxdde ovolved was swopt Into an absorption tower conteining a $16 \%$ sodiue hydroxdde solution $(35,43)$. An allquot of the sodiun hydroxdde solution was dissolved directiy in the scintillator solution and counted.

Methrelemine. An aliquot of an aqueous solution of the irradieted oyanoguanidine with carrier mothylanine added was cooled in an ice bath for apprordmately 10 minutes. Phenglisothiocyanate vas added and the solution shaken rapidis for 3-5 minutee. (") Frecautions were taken to avold adding an excess of the phenjlisothiceyanate to the aqueous aample sinee an exoess of the isothioeganate producee yellow o1l which is very diffieult to separate from the soldd derivative. The precipitate was flltared, washed with a cold 50 s aqueous ethanal solution and repested1y rocrystallized to a constant specific activity from 95\% ethanol. (37) A welghed portion of the N, N'Methylphenylthiourea was dissolved directly into the seint1ulator solution and its activity determined.

Urea. Jack bean urease was added to an aliquot of an aqueous solution of the Irradiated sample containing carrier urea; this solution had been previously buffered to a pH of 6.8-7.0 with phosphate buffer solution. (38) The solution was allowed to stand at room temperature for 22 hours and then

(i) Secondary amines, such as dimethylamine, also react to form the phenyl thiourea derivatives. 
was treated with an excess of dilute sulfuric acid. The carbon dloxdde evolved was awept Into an absorption tower containing a $16 \%$ sodiun hydroxdde solution. (59) A known volume of the sodium hydroxide solution was dissolved directly in the seintillatior solution and counted.

Cranomanidine. Carrier eyanoguanidine was disaolved in an allquot of an aqueous solution of the Irradiated sample by warming. Care was taken to avold heating the solution above $800 \mathrm{C}$, since cyanoguanidine decomposes slowly In water above this temperature, liberating amonia. Ifter coollng, the orgatals were separated by filtration and recrystallised from distilled water to a constant specific activity. In allquot of the cyanoguanidine was dissalved in water, added to the seintillator solution, and counted.

Granidine. Cyanoguanidine was removed frow an allquot of an aqueous solution of the sample as described above. To the filtrate was added carrier guanidine and then a saturated solution of oxalle acid; guanidine oxalate separated from the solution as white crystals after the addition of ethanal to the equeous solution. The precipitate was filtered and recrystallized from an ethanol-water mixture to a consisnt apecific activity. The precipItate was dissolved in hydrochlorie acid and the solution was then added directly to the scintillator solution for the determinstion of the carbon-14 activity.

Netamidine. An aliquot of an aqueous solution of the irradiated ample, containing carrier acetemidine, was made strongly basic with a $16 \%$ sodiva hydroxdde solution and heated gently. After cooling, the solution was adjuated to a ph of 7.0 with dilute hydrochloric aeid. To this was added a hot sthanol solution contalning bensylthluronium chloride. The precip- 
1tate was $f 1$ tered, weshed with water and recrystallized to a constant specific activity frot dioxane.(37) A welghed portion of the derivative was dissolved in $95 \%$ ethanol and added directly to the scintillator solution.

Methylhydrasine. After adding carrier methylhydrazine, a $50 \%$ aqueous sulfuric ac1d solution was added to an aliquot of an aqueous solution of the sample at $0^{\circ} \mathrm{C}$. The precipitate, formed upon the addition of $95 \%$ ethanol, was flltered and recrystallized from $80 \%$ ethanol to a constant pociflc activity. A welghed portion of the precipltate was dissolved in sodium hydroxide and added to the scint1liator solution.

icetonitri1e. Methylamine and formaldehyde vere removed from an aliquot of an aqueous solution of the sample, after carrier addition, by precipitation as described previousiy. The acetonitrile was removed by diatillation ualng carrier techniques, and dissolved directly into the scintillator solution; the activity of the sample was then deternined.

Polverte Materiel. Upon dissolution of samples of the Irrediated eyanoguanidine in dist1lled water, a brown waterial was found to realin undissolved. The brown solld was found to be only alightly soluble in water.

Ten millisters of distilled water were added to a 0.3 gm sample of the Irradiated cyanoguanidine and the solution centrifuged. The procedure was repeated with another distilled water wash and finally with acetone. The acetone wes removed by air evaporation and the solld dried at $1200^{\circ}$ for 30 mimutes. The brown solld was dissolved in sodium hydroxide, added to the seintillator solution and counted. The broun polymerie material was found to contain about $13 \%$ of the total actirity. 
A portion of the brown material was mixed thoroughly with a small amount of mineral oil to form a mull and subjected to infrered analysis using a Porkin-miner Model 137 Infracord Spectrophotonetar. An Infrered analysis of authentic melasine in a similar mineral oll mull was also obtalned. The infrared analyals of the brown waterial showed the aame aboorption bands, particularly the signifleant 12.25 allimieron bend, as those obtained for the pure aelamine, Indicating that at least a portion of this polymeric material is molanine.

Pure melanine has been reported to show a sharp ultreviolet absorption band at 236 milliulerons(29). A small sarple of the brown solld was dissolved in $0.1 \mathrm{~N}$ bydrochloric acid and the vitraviolet speotrum was mede using a Cary Model 11 Recording Spectrophotometer. An ultraviolet spectrum was also obtelned for a sample of authentfe melanine in 0.1 a bydrochloric acid. The analysis of the pure melentine showed a reasonable sharp absorption at 236 millialerons, followed immedintely by very broad, Intense absorption band extending to bout 200 millinlerons. The analysis of the brown material did not show a sharp absorption at 236 millimferons; however the broed absorption band observed for the authentic melamine was observed in the analysis of the brown material. These results suggest that other materlals are present In the brown solid in addition to melanine.

The solubility of pure melanine has been reported in The Merck Index(39) to be slightly soluble in water at $20{ }^{\circ} \mathrm{C}$. An approximate correction for the solubility of the brown aterial in water has been applied in reperting the total activity deternined. 


\section{Radiochenteal Counting Techniques}

Carbon-14 was the only radioactive element present in the irradiated eyanoguanidine. This eliminated any preferential determination of one isotope wth regards to another isotope present in the sample and also elininated any posibility of contenination in the seperation of the various fraction by another 1sotope preaent in the ample.

Carbon-14 deears by negatron emission with a half-11fe of 5760 years(26). The IOW energy of the entted beta pertieles influences the cholee of techniques to be exployed in counting the carbon-14 aotivity. The two principle mothode employed in this study were lonization chamber counting of geseous samples, and Ilquid seintillation counting of solutions. As vas mentioned earlier, proportional counting vas employed for a feu radioanalyais made using gas chronatographic techniques.

Ionisation chamber connting techaniques using a vibrating reed electrometer were enployed for gasecus amples. The gaseous sample to be eounted was allowed to enter the evacuated lonisation chamber and the chamber elosed off by nean of a valve. Inective, anhydrova carbon dioxide was uaed to bring the presarre in the chamber to atmospherie preesure. The 1onisatIon chamber was placed on the vibrating reed electrometer head, allowed to reach equilibrium and the ectivity weesured by the rate of drift nethod at 105 volta. This method of activity determination was not entirely satisfactory, however, due to the long perlods of time required for the gaseous aanple within the lonisation chamber to reach equilibriun. In wany cases, up to 72 bours vas required before the aysten reached equilibrium. The necesalty to convert all of the derivatives isolated in the analysis to carbon 
dioxdde and the inability to reproduce many of the reaults also contributed to the dissatisfaction with this method. Therefore, results obtained by these means were discarded, and emphesis placed upon liquid seintillation counting.

The Ifquid seintillation counting technique proved to be a very versatile and convenient method for the detormination of the activity isolated in the analysis. Each derivative isolated wes dissolved either directly or by use of a suitable solvent into the selatillator solution. The direct dissolution of the 1solated material was preferred when foasible. All activity messurements were made using a Packard Tr1-Carb Liquid SeIntillation Spectrometer(31). The voltage on the two photomultiplier tubes had an average value of 840 volts. The attenuators were set at 1.0 , which caused an anplification of the pulses recelved from the pre-ampliflers of about 3,000. With the low-level discrivinator sot at 10.0 and the high-level discriminator set at 50.0, the gate width was set on the maximum energs of the 0.155 Mer beta partiele enitted from earbon-14. The seintillator solution used in this study consisted of a solution of 50.0 mg of POPOP ( $1,4-\mathrm{bls}-2$-(5-phenyloxasole) benzene), $7.0 \mathrm{gm}$ of PPO $(3,5$-diphengloxasole) and $100 \mathrm{gm}$ of naphthalene in ose 11ter of p-dioxane. A counting efficieney of $(50.0 \pm 1.4)$ was obtained using standardisation samples of benzole acid-cll obtained from three different sources $(18,32,42)$. The error quoted abore is one stendard deviation.

Counting efficieney studies were perforned on each derivative solute counted in these determinations. The effect of some typical added epmponents on the counting efficiency of the scintillator solution described above is given in Flgure 2. Figure 2 shows that both the adition of N, I'-methylphenylthiourea and concentrated ammonium hydroxdde decrease the counting efficieney of the seintillator solution warkedy. The addition of water to the seintillator 
solution effects the counting effleleney of the seintillator solution to a much snaller extent. A plot of the theoretical count rate and the observed count rate a function on concentration of $N, N^{\prime}$-methylphenylthiourea is given In Figure 3. The broken IIne is the theoretical count rate based on the carbon-14 concentration and the solid Iine is the count rate experimentally observed. It has already been obeerved that the addition of the $\mathrm{N}, \mathrm{N}$ '-methylphenrlthiourea decreesee the counting efficiency of the seintillator solution. A plot of $\log (\mathrm{I} / \mathrm{C})$ veravg $C$, where II the counts per winute and $C$ is the concentration of the $\mathrm{N}, \mathrm{N}^{\prime}$-methylphenglthiourea, is shown in Figure 4. The half-quenching concentration value of $28 \mathrm{mg}$ obtalned from this study is comparable to the value of 25 ag for a sintlar compound, q-tolylphenylthiourea(33).

The samples were prepared for counting by efther dissolving the carrier derivative directly into the selntillator solution or by dissolution into a miniman anount of a suitable solvent. The counting viels consisted of a special glass, deaigned especially for liquid scintillation counting. Ifter dissolution of the sample into the seintsllator solution, the sample rials were cooled for 5-10 minutes prior to counting. The effect of the carrier derivetive on the counting efficlency of the scintillator solution was determined for each carrier 1solated. In this manner, corrections for the decrease in the counting efflelency of the seintillator solution were applled to the ealeulations of the specifle activity of the particular carrier. 


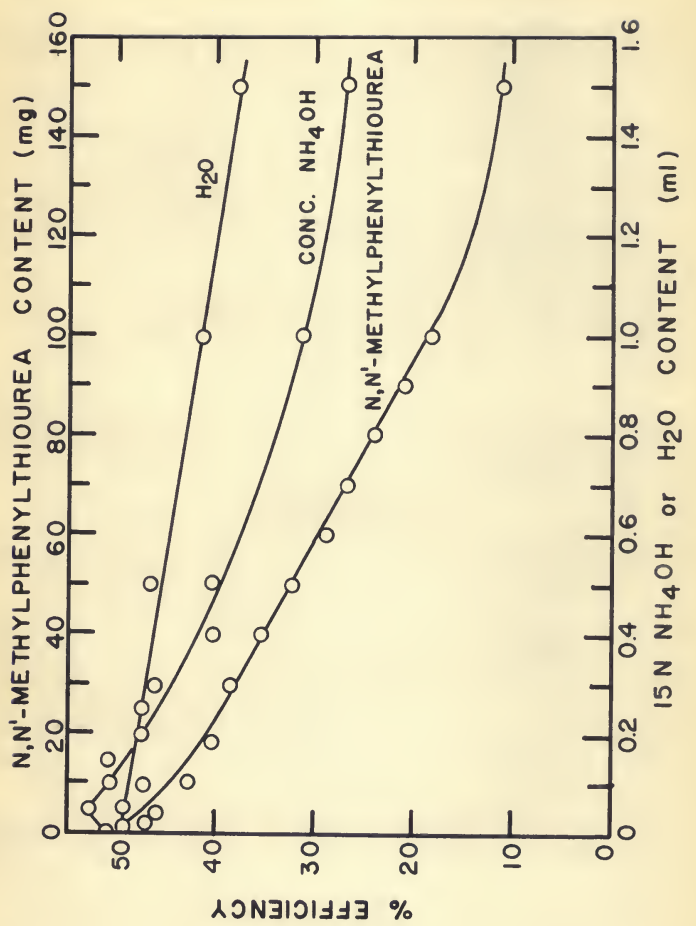

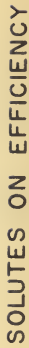

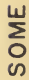

4

占

N

崩 


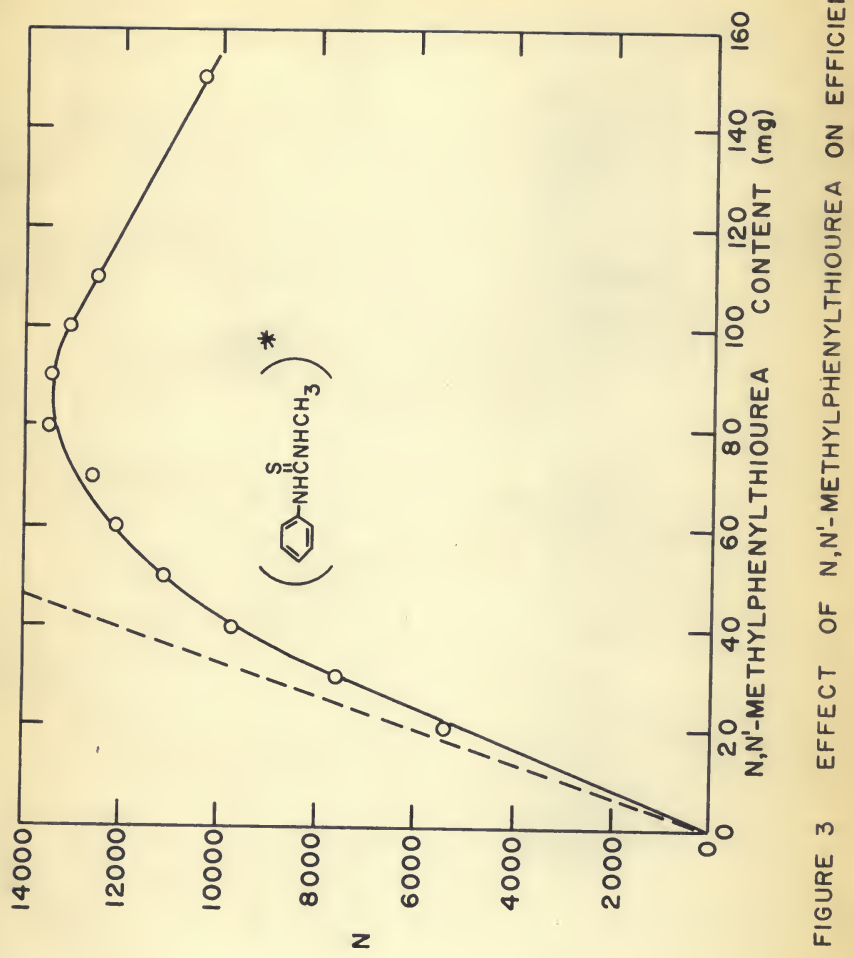




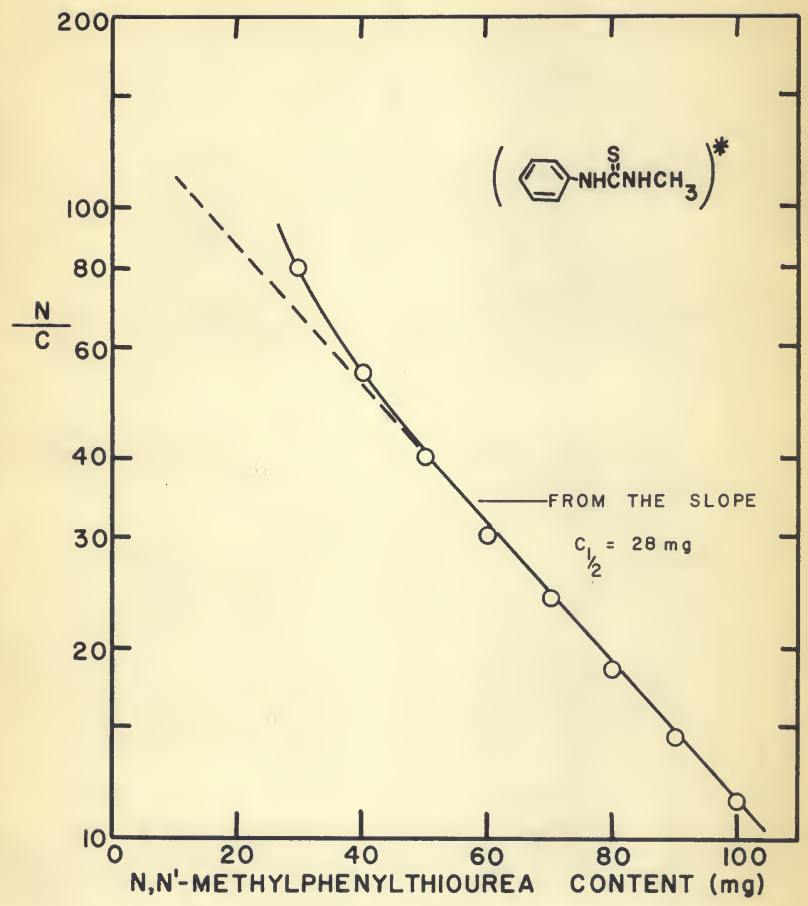

FIGURE 4 LOGARITHMIC PLOT OF FIGURE 3 


\section{RESULIS AND DISCUSION}

One of the important reaulta obtained In this study is the essentially counglete detarnination of the carbon- 14 contalning compounds produced by the neutron Irradiation of complex organic eompound in the crystalline state. Previous studiee have shown that a complete deternination of all the chenceal specios contalning the reooll carbon-14 atom has been essentially Iinited to Inorganie and siaple organie eompounds. Results have shom that in complex erystalline arganle ecepounds, only 25-50 per eent of the total activity Indueed into the sample by the neutron irradiation is uaually isolated in stable chenical species.

The total carbon-14 activity of the irradiated sample vas dotermined by dissolution of a known portion of the solid in vater. Ulquots were taken of the dissalved sample and the totel activity deterained by liquid selntillation counting. The average of four different determinations made over a period of four months was $18.6 \pm 0.7$ mierocurles for the 4.952 gin sample; 10., a spelfle aotivity of $3.76 \mathrm{\mu C} / \mathrm{gm}$. The error quoted is one atandard deviation. The totel amount of carbon-14 activity expected for the anple was calculated to be 31.1 ilerocurles, based on the carbon- 44 half-1ife of 5,760 years and an antielpated 1rrediation time of 672 hours. The pille neutron Irrediation of the sample produced approxdmately 60 per cent of the caleulated activity. This value is not umreasonable since the pile is shut down for loading and unloading operations four dars of the wonth and ance the exact aeutron Nux at the location of the sample position in the pile was not known.

The results obtalned by the 1solation procedures deecribed in the 
Experimental Section are given in Table 1. In all cases, the data reported are besed on speific activity measurements. The percentage activity is based on the total activity of an allquot of an aquecus solution of the origInal Irrediated eyanoguanidine sample. The total aetivity isolated in this strudy was 90.1 per cent of the total carbon-14 activity Induced in the cyanoguanidine sauple by pile neutron Irradiation.

In this Investigation we have considered only the final obemical farm Incorporating the recoil carbon-14 atom. It has been previously suggested (56) that many chemical sorme of the recoll carbon- 14 atom are present within the solid matrix following 1rradiation. Kany of these matrix-stabilized chemical form undergo decomposition, reerrangement or further reactione when the solsd Irradiated compound is dissolved in water to give chemicelly atable specles which wo be 1solated from an aqueous solution of the 1rradiated compound. Since only the final form assumed by the reeoll earbon-14 is setually determined, these matrix-stabilised species can be arrived at only by a eritical anelysis of the results obtalned from a particular deternination and the prom poeition of reasonable intermediates to yield the products actually observed. From the consideration of a number of studies, similarity in the final form of the recoll aton may become evident. Considerations of the similerities can leed to better characterization of the matrix-stabilised specles resulting from the 1rradiation.

The final state of the carbon-14 recoll atom may be conaldered in terms of three stope, any one of which may have an effeet upon the final distribution of activity. (50) The first stepe involves the reduction of the enerco of the recoll atco by elastic and inelastic collisions and the finel locellation 
Tablo 1.

praction
Per cent of Totel setirity

\section{Average}

$\mathrm{CH}_{4}$

co

$\mathrm{CO}_{2}$

ach

หсно

HCOOR

$\mathrm{CH}_{3} \mathrm{CH}$

$\mathrm{CH}_{3} \mathrm{NH}_{2}$

$\mathrm{CH}_{3} \mathrm{NHNH}_{2}$

$\left(\mathrm{NH}_{2}\right)_{2} \mathrm{CO}$

$\left(\mathrm{MH}_{2}\right)_{2} \mathrm{C}=\mathrm{NH}$

$\mathrm{CH}_{3} \mathrm{C}$ ( $\left.\mathrm{HH}\right) \mathrm{NH}_{2}$

$\operatorname{MCNBC}(\mathrm{NH}) \mathrm{NH}_{2}$

Melamine
Average

0.0

0.0

0.0

0.0

0.1

0.4

0.6

3.2

1.0

0.2

13.5

16.9

41.1

13.1

Carbon-14 Distribution Mong Various Compounds

Values Obtained

$$
\begin{aligned}
& 0.0,0.0 \\
& 0.0,0.0 \\
& 0.0,0.0 \\
& 0.0,0.0 \\
& 0.2,0.1,0.1 \\
& 0.5,0.4,0.4 \\
& 0.9,0.3 \\
& 3.3,3.1 \\
& 1.3,0.7 \\
& 0.4,0.2,0.1 \\
& 14.3,14.1,13.9,12.9,12.4 \\
& 17.7,17.0,16.6,16.2 \\
& 42.6,39.6 \\
& 13.5,12.7
\end{aligned}
$$


of the recoil atom in a reactive s1te. The second step involves the chem1eal considerations which may lead to a verloty of solid matrix-stablized chemieal spec1ed depending upon the structural aspects of the entrapnent site and upon the enerey available for chemical reactions within the reective 1te. The third atep considers the collaspe of the solld matrix-stabilized apecies to form stable compounds or the reaction of the atabilised apeciea during subsequent chemieal operations carried out on the Irradiated material to form stable chemical species. Each of the foregolng stops, however, Involves several fectora.

Factors to be conaldered in the flrst step ares (1) the energy of the recoll atow or frageent previous to the final localization in a reactive a1te, (2) the structural aspects of the recolling atom or ragment during the perlod before the flnal locallsation, and (3) the probability of Interaction of the recoll atom or fragment with a partieular bond, nolecule or atom. The factors involved in the second step include: (1) the probebility of the formation of number of ehemieal apecles which will lead to the formation of stable products, (2) the effect of the aurroundings on the flnal distribution of the recoll atom anong the various products. The third step involves: (1) the probability that an intermedlate will collapse to give a stable compound, and (2) the consideration of whether or not a compound can be isolated by the chemical procedures employed and the Innuence of the separation procedures on the activity distribution.

\section{Distribution of Carbon-14 Reco1l Aton}

The absence of activity in the oxygen-containing gases evolved from the sample upon dissolution in vater would be expected since oxygen was not 
originally present within the molecule. This absence supports the results obtained by Iankwich $(56,59)$ for ammonium bronide and amioniun sulfete. In the oxygen-contalning conpound, 42 per cent of the activity was present as carbon dioxdde and carbon monoxide while in the ammonium broulde only 3 per cent of the total activity was present in carbon dioxide and carbon monoxdde. The relatively small amounts of activity present in the "aimpler" compounds, such as formaldehyde, hydrogen cyanide and formic ac1d, Indicatea the formation of skeletons of complex chenleal species and that these speoles persist In the irradiated crystals. Formation of the "singler" compound would occur by the presence of a matrix-stabilized intermediate species such as $\mathrm{CH}_{2}=\mathrm{NH}$, which when dissolved in water would undergo hydrolysis to form formaldehyde. The results indicate that the fragmentation of the surrounding molecules by the recol1 carbon- $u_{4}$ aton does not produce a complete dissociation of the molecules, but rather leads to the formation of two or three larger fragments of the parent molecule. This could explain the absence of activity in the "simpler" coupounds.

An Important result of this study is that nearly one-half of the total activity produced in the pile-neutron irrediation was found in the parent compound, eyanoguanidine. This differs signifleantly rom results previously reported (47) in which only a suall fraction of the total activity has been "retained" in the perent compound. The formation of the eyanoguanidine mey be postulated to occur by equations (I) and (2).

$$
\mathrm{H}_{2} \mathrm{MC}(\mathrm{NH}) \mathrm{NHCN} \stackrel{(\mathrm{n}, \mathrm{p})}{\longrightarrow} \text { reco11 } \mathrm{Cl}^{\mathcal{H}_{4}}+\text { molecular fragments }
$$

and 


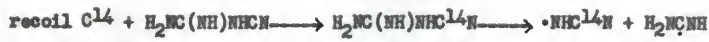

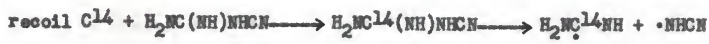

Tho carbon-16-ontaining cyanamide redieals, resulting from the fragnentetion of the parent compound, wight subsequentily diserise, elther with each other or with other Inactive eyanamide radicals produoed by the fragmentation of the eyanoguanidine molecule to reform the perent compound. This possibility becones nore plausible in 11 ght of the results obtained by Ma(25) In the thermal decomposition strudies of guanidine chromate and granidine dichromate. Ma found (25) that at elevated tempersatures oyanamide was produced and the major share of the eyanamide dimerised to form eyanoguantdine. By considering the temperature attalned in the local hot-spot reglons aceording to the Se1ta-Koohler (36) description of the displacement of atoms, It appears reasonable that the high "retention" of the Induced carbon-14 activity In the parent compound oceurs by the formation of eyanamide, which dimerises within the locel hot-spot region to form eyanoguanidine.

The formation of the two eyanamide radicels resulting from a "knoek-on" reaction with the recolling earbon- 14 stom may be rationalised by conalderation of the nature of the groups attached to the central carbon atom and the edfacent nitrogen atcom. In organie chenistry, the CaN group is considered a moderately strong electron attracting group. The Call group may attrect electrons and consequently tom to veeken the bonding between the nftrogen and earbon in the single bond. The nitrogen atow would now be somewhat defielent of electrons and, being more electronegative than carbon, would tand to attraet the electrons from the alngle bond between itself and the central carbon atom. The attraction of these electrons would veaken the 
alngle bond between the nitrogen and the central carbon atcon. The Inine Eroup, bonded to the central earbon atom, is also an electron-attracting group, although not as atrong at the CEN group. Attraction of electrons by this group would also weaken the aingle bond between the central carbon atom and the nitrogen atom. Brom this consideration of the nature of the Eroupe present In the eyanoguanidine molecule, one could reason that the alngle bond between the central carbon atom and the nitrogen atom is perhapa the weakest bond within the molecule. This bond would most IIkely be broken by the "knock-on" reaetion with the reoolling carbon- 4 atom.

At least a portion of the polgmeris anaterial observed in this study hes been tentatively Identified as melanine. Infrared and ultraviolot spectrophotometric results have shown that a component of the polymerie naterial is melamine. The possibility of other chemical species, in much smaller amounts, cannot be disregarded, however. In view of the actual anount of the material 1solated, complete analysis of all components present in the polyweric solld would be extremely difficult. It is apecwlated that the formation of melamine oceurs in much the same manner as the formation of eyanoguanidine. The formation would involve a trimerisation of the oganouide radicals produced within the local hot-apot regions. This speculation is supported by Glasner and Makoviky's(12) studies of the thermal decomposition of euanidine perehlorate in which they report that guanidine perchlorate dissociates in the region of $300-450^{\circ} \mathrm{C}$ to give considerable mounts of eyanamide, which trimerises at elevated temperatures to form melanine. It 1s auggested that

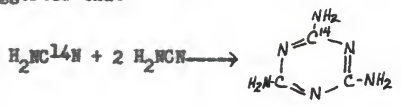


The results of this study have shown that, in addition to the perent compound and the polymerie naterial, a agnifleant anount of activity (> 10\%) was found in only two other compounds, guanldine and acetanidine. A possible mechanism for the formation of guanidine is

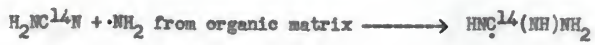

and for the formation of acetamidine, possible mechanisms are

$$
\begin{aligned}
& \mathrm{C}^{\mathrm{H}_{4}} \mathrm{H}_{3} \cdot \mathrm{H}_{2} \mathrm{NCN} \longrightarrow \mathrm{H}_{2} \mathrm{C}^{\mathrm{U}_{4} \mathrm{C}}(\mathrm{NH}) \mathrm{NH}_{2} \\
& \left(\mathrm{CH}_{3} \text { or } \mathrm{C}^{\mathrm{U}_{4} \mathrm{H}_{3}} \cdot\right)+\mathrm{H}_{2} \mathrm{NC}^{\mathrm{U}_{\mathrm{N}} \mathrm{N}} \rightarrow \mathrm{H}_{2} \mathrm{C}^{\mathrm{UCH}_{4}}(\mathrm{NH}) \mathrm{NH}_{2} \text { or } \mathrm{H}_{2} \mathrm{CC}^{\mathrm{U}_{4}}(\mathrm{NH}) \mathrm{NH}_{2}
\end{aligned}
$$

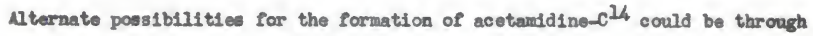
the "knock-on" reactions,

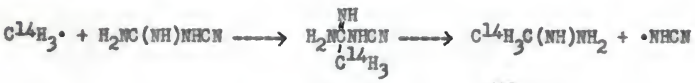

$$
\begin{aligned}
& \left(\mathrm{CH}_{3} \text { or } \mathrm{C}^{2 \mathrm{H}_{3}} \cdot\right)+\mathrm{H}_{2} \mathrm{NC}^{24}(\mathrm{HH}) \mathrm{NHCN} \longrightarrow \\
& \mathrm{C}^{14} \mathrm{H}_{3} \mathrm{Cl}^{14}(\mathrm{HH}) \mathrm{NH}_{2} \text { or } \mathrm{CH}_{3} \mathrm{C}^{2 / 4}(\mathrm{NH}) \mathrm{NH}_{2}+\cdot \mathrm{NHCN}
\end{aligned}
$$

The recolling carbon- 14 is a very reactive radical and when 1 ts ation becomes essentially diffuse, the carbon-14, can react with its surroundings to produce a variety of molecular apecies $(50)$.

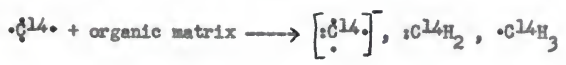

The carbon-14 conteining nethyl radical may then undergo the reactions postulated in equations 5-8. The carbon-14 containing compounds obtained through auch a mechantsm would contain $C^{14}$ atoms either in the aethyl group 
or at both earbon pesitions. The production of aceturaldine with the earbon-16 only in the central carbon poultion would require the formation of an unlabeled methyl radieal, sinee a methyl group, as auch, does not oxiat in the oyanoguenidine moleoule. The formation of this methyl radical may be postulated in weh the same manner as that suggested by equation 8. The carbon radical could concelvable be formed as a reeult of fragmentation due to the recolling $\mathrm{C}^{14}$ atom through the organic matrix.

Cyanoguanidine, contelning the carbon- 14 atom at el ther carbon position would require the dimerisation of a labeled cyanenide redical with an unlabeled eyeneaide radieal produced within the same hot-ipot. The formation of doubly-laboled eyanogunnidine, however, would require the dimerisation of two labeled cyananide radicels. This vould necessitate the difrusion of one of the labeled radicals through the ergstalline orgenle matrix to

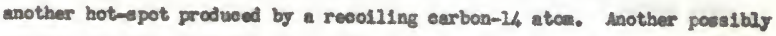
could be that in the combination of the various hot-spots to form a hot sone or "displacenent apike", two labeled eyananide redicals may oceur vithin a proxdmity suffielently close to ellow the diwerlzation of the two redicalo to farm the doubly-labeled oyanoguanidine molecule. One could reasonably assume the probability of two Iabeled eyanamide radicals diverising to form the doably labeled parent ecmpound is low and that the eganoguanidine woleoule is labeled in elther of the carbon positions but only to amaller extent in both positions. In the forwation of melavine, essentially the samo mechantan ay be postrileted ws for the formation of cyanoguanddine. The most probablo pecio resulting from the trimerisation of three cyannatde radicals to form the nelmine molecule would be one which contalns a carbon-lh atcoes at only one of the carbon position. The probabsisty for the formation of a teiply 
labeled molecule, necessitating the trimerisation of three labeled oyananide radieals, would 11kely be very low. The probability for the formation of a doubly labeled specio would also be expected to be small.

\section{Radicarbon Produet Distribution}

Yankwieh(55) has stated that ohemical consequences of the two different final environmental situations, predicted from the L1bby $(20,21)$ and SeitsKoohler (36) models, would be quite similar for simple lonic eryatels. A different chemical phenomena would oceur for molecular erystals or lonfe solids containing molecular 1ons. Production of a long-lived, high temperature hot-spot, predieted by the Libby model, would probably involve the canplete dissociation of the molecule or molecular ion in the vicinity of the hot atom. As cooling occurred, competitive reactions anong the various atoms would determine the nature of the chemical species observed upon dissolution of the target in a solvent. Whare a short-lived, lower terperature hot-spot is produced, as predicted by the Selts-loohler model, only pertial fragmentation of the molecule or molecular lon would likely result. Upon cooling, competitive reactions among varlous atoms and fragments would determine the distribution of radiocarbon in the various chamical species upon dissolution in aufteble solvent. The Libby model predicts a concentration of enerey sufficient to permit the formation of species capable of oxidiaing the recoil carbon-14 atom; the Se1tz-Koehler model prediets that much less energy will be available within the hot-spot and that species capable of oxddizing the recoll atom would not be formed.

In simple ionie crystals where a few carbon-corteining species can be formed and where only one or two types of hot-spot onvironment can oceur, 
the amount of energy available in the terminal hot-apot may exert a strong influence on the final chemical state of the recoil ator. The distribution of product radicoarbon among the various oxdation states may be a reflection of the distribution of energy in the terminal hot-apots. Libby's nodel prediets a dependance of the final chemical state upon the recoll anergy of the atom. In the Seltz-Koohler model, no processes have any chemical consequences prior to the entrapment of the recoll atom so that the varlation of recoll onergies has no effect upon the IInal chemical state of the recoll atoms, provided the recoll energy is greater than the entrapment energ.

If the charges on the ions in a simple lonic crystal are aimilax, one would expect the carbon-14 recoll atom to exhibit a symetrieal distribution of axldizing and reducing character resulting in a symetrical distribution of the radiocarbon among the varlous oxddation states, providing the reactions of the entrapped radicals are not entirely of one nature.

The distribution of the recoll carbon-14 atom among the various oxidation states for several compounds is shown in Table 2. In the foregoing discussion, 1t was stated that aimple lonic crystals should show a symetrical distribution of the radicearbon anong the various oxddation atates, while the distribution for moleevles or lonie solids containing moleoular lons depends upon the competitive reactions oceuring within the hot-spot. The distribution of the redicearbon among the various products in the beryllitum nitride study confirne the expectation of a symetrical distribution of the recoll atom among the various exdastion states in a simple lonic erystal. If one comparea the totel activity oecurring in the negative oxddation states with that oceurring in the positive oxddation atates, an essentially equal 
Table 2. Distribution of Carbon-14 Anong Various Minal Products of the $(n, p)$ Reaction on Mitrogen-Containing Conpounds

\begin{tabular}{|c|c|c|c|c|c|c|}
\hline $\begin{array}{l}\text { Oxdn. } \\
\text { No. }\end{array}$ & $\begin{array}{l}\text { Final } \\
\text { Product }\end{array}$ & $\mathrm{H}_{2} \mathrm{MC}(\mathrm{MH}) \mathrm{MHCN}$ & $\mathrm{NH}_{4} \mathrm{Br}$ & $\left(\mathrm{NH}_{4}\right)_{2} \mathrm{SO}_{4}$ & ${ }^{\left(\mathrm{HH}_{4}\right)_{2} \mathrm{C}_{2} \mathrm{O}} 4$ & $\mathrm{Be}_{3} \mathrm{II}_{2}$ \\
\hline Ror. & & * & 59 & 56 & 11 & 57 \\
\hline-4 & $\mathrm{CH}_{4}$ & 0.0 & 7.5 & 0.5 & & 25.8 \\
\hline \multirow[t]{2}{*}{-2} & $\mathrm{CH}_{3} \mathrm{HH}_{2}$ & 3.2 & 79.1 & 16.1 & & 4.1 \\
\hline & $\mathrm{CH}_{3} \mathrm{NHNH}_{2}$ & 1.0 & & & & 11.2 \\
\hline 0 & всно & 0.1 & 5.8 & 13.2 & & 2.4 \\
\hline \multirow[t]{4}{*}{+2} & CO & 0.0 & 1.3 & 2.0 & 4.8 & 0.1 \\
\hline & $\mathrm{BCOOH}$ & 0.4 & 1.3 & 15.5 & & 8.3 \\
\hline & $\mathrm{HCX}$ & 0.0 & 2.0 & 3.9 & 1.5 & 6.5 \\
\hline & $\mathrm{CH}_{3} \mathrm{CII}$ & 0.6 & & & & \\
\hline+3 & $(\mathrm{COOH})_{2}$ & & & & 21.3 & \\
\hline \multirow[t]{6}{*}{+4} & $\mathrm{CH}_{3} \mathrm{C}(\mathrm{NH}) \mathrm{NH}_{2}$ & 16.9 & & & & \\
\hline & $\mathrm{CO}_{2}$ & 0.0 & 1.7 & 39.5 & 5.8 & 24.4 \\
\hline & $\mathrm{CO}\left(\mathrm{HH}_{2}\right)_{2}$ & 0.2 & 0.4 & 7.3 & & 6 \\
\hline & $\mathrm{CNH}\left(\mathrm{MR}_{2}\right)_{2}$ & 13.5 & 0.0 & 0.0 & & 18.7 \\
\hline & $\mathrm{H}_{2} \mathrm{KC}(\mathrm{MH}) \mathrm{MHCN}$ & 41.1 & & & & \\
\hline & Melamtine & 13.1 & & & & \\
\hline
\end{tabular}

- Reeult or this study 
distribution is found. The ungymetrieal radiocarbon diatribution anong molecules and fonic erystals containing molecular lons is clearly demonstrated by the remaining compounds in Table 2. The amonium bromide, sulfate and oxalate are lonic crystals conteining a molecular ion, the anmonive lon, while cyanoguanidine 18 a molecular crystal. The results obtalned in the amonium bromide study show approxdmately 90 per cent of the activity present In the negative oxddation states with almost 80 per cent of the activity present in the negative two oxdation state. In sharp contrast, ammonium sulfate and cyanoguanidine have shown 68 and 86 per cont, respectively, of the total activity present in the positive oxddation states, w1th 85 per cent of the total eotivity of cyenoguanidise and 47 per cent of the activity of amonium sulfate occurring in the positive four oxddation state. The results obtained for ammonium oxnlate are incomplete, with only 24 per cent of the total setivity determined. The results, hovever, show all the activity obeerved is present in the positive oxddation states.

The results of the present study on the neutron irradiation of crystelIne eyanoguanidine agree ver; well with the reaults previously reported for other systens irradiated in the erystalline state in showing the unaymmetricel distribution of the reooll carbon- $\mathcal{L}_{4}$ atom anong the various oxddation states of the radiocarbon products resulting from molecules and 1 anic ollds containing molecular ions. 


\section{SU SURY}

sotivity measurements vere made using 11quid scint1llation counting teohniques. A counting efficiency of $(50.0 \pm 1.4)$ per cent was obtained using seintillator solution consisting of POPOP, PPO and naphthalene in b-dioxane. The effect on the counting efficiency of the addition of various solutes to the scintillater solution was also studied.

The neutron Irradiation of erystalline eyanoguanidine produced the Incorporation of the recoll carbon-14 atom in several stable chendeal species. The perent compound, eyanoguanidino, was observed to contain approximately 40 per cent of the total activity produced by the neutron Irradiation. Cuanidine, acetanidine, and a polymeric material, believe to be melamine, were found to contain 17, 13.5, and 13 per cent, respectively, of the total activity induced in the sample. Small amounts of activity were found in the form of formeldehyde, forme acid, mothylanine and acetonitrile.

Reaction mechanters, Ieading to the final Ineorporation of the earbon-14 recoil atom in the chesical apeeies isolated, were postulated. The cyanonide radical, produced by the rragnentation of the cyanoguanidine, wes anggested to be the principle intermediate in the fornation of eyanoguanidine, melanine, granidine, and acetanidine.

Radiation danage, due to the gama-ray R Iux aceompanying the thermal neutrons in the pile irradiation, was calculated to have damaged about 12 per cent of the sample. 


\section{ACKNOWLLDCMEMS}

The author vishes to express his deopest and most sincere appreciation to Dr. R. W. Kiser for his guidance, oncouragement and helpfol suggestions during the course of the research.

Appreciation 1s elso expressed to Professor H. C. Moser and Mr. R. D. Shores for the gas chromatographic radioanalysis of mothane and carbon monoxide. The author also wishes to express special thanks to $\mathrm{Yr}$. D. W. Rathburn for aid in the semple preparation, for the use of special equipment during the course of this study, and for discussions of portions of this work.

Th1s research was supported In part by a erant froen The Petroleve Research Fund administered by the Meriean Chemical Society. Grateful acknouledgrent is hereby made of such fund. The author wishes to thenk The Petroleun Reseurch Fund for the award of an "American Chemical SoeletyPetroleum Resoureh Fund Fellowship", held during the tenure of this vork.

Grateful appreciation is also expressed to the V. S. Atamie Inergy Comission for partial support of this work. 


\section{REF RENCES}

(1) Ajzenberg, F., and T. Lauritsen, Revs. Nodern Phes., 2h, 321 (1952)

(2) Barbleari, R., U. Bellueo and M. Bruno, Gagz. chim. 1tel., 87, 1377 (1957)

(3) Bellueo, U., R. Barbiar1, and G. Sehiavon, Gasa. chin. 1tal., 88, 78 (1958)

(4) Cacace, F., L. C1er1 and K. zifferero, Lun. ehin., 47, 892 (1957); C.4., 52. 17511 (1957)

(5) Geace, F., G. Giaconello and G. Montetinale, Gass. chim. 1tal., 89, 1829 (1959)

(6) Collins, C. G., and V. P. Callins, Apex. 261, dircraft lluclear Propulsions Dept., General Ilectric Co., Cineinnati, Ohio, p. 18-31. (D. W. Sotser, K. S. Thes 1s, Kansas Stato UnIversity, Manhattan, Kansas, 1958.)

(7) Duckworth, H. E., Rers. Nodern Phre., 22, 767 (1957)

(8) Pransen, W., J. Halpern and W. E. Stephons, Phve. Rex., 27, 641 (1950)

(9) G1acomello, G., Rlearen Se1., 21, 1211 (1951); C.4., 47, 10352 (1953)

(10) Glaconello, G., U. Croatto and A. E. Maddock, 1b1d, 21, 1598 (1951), (soe Wolf, A. P., Anger, Chem., 71, 237 (1959)

(12) Giacomello, G., and M. Z1fferero, Ann. chim., L4, 558 (1954)

(12) Glasner, Aos and A. Makoviky, J. Chem. Soc., 1953, 182

(13) Gould, E. S., "Inorganic Reactions and Strueture", Henry Holt and Co., Mew York, 1955, p. 136

(14) Harbottle, G., and N. Sutin, I. Phrse. Chem., 62, 1344 (1958)

(15) Hoin, R. E., D. W. Sotser, C. J. Terhaar, S. C. Chang, R. H. McFarland and M. F. Hansen, Seience, 125, 195 (1957)

(16) Horning, E. C. and M. G. Horning, I. Org. Chem., 11, 95 (1946)

(17) Hughes, D. J., and R. B. Sehwarts, Mlleutron Cross Sections", BNI-325, 2nd Edition, ט. S. Government Printing Office, Weshington, D. C., July 1,1958, p. 4 .

(18) Isotope Specialities Co., Lot. No. 13A30595-1, sp. act. $=20300 \mathrm{dps} / \mathrm{gm}$

(19) Xotz, X. M. and T. Askounis, I. Am. Chem. Soc., 62, 801 (1947) 
(20) Lubby, W. P., I. 쓰. Chem. Soc., 62, 1930 (1940)

(21.) Libby, W. T., 1bid, 62, 2523 (1947)

(22) Lubby, W. F. and C. F. Mackay, Intl. I. Appl. Rad. Isotopes, 2. 256 (1957)

(23) Libby, W. F. and C. F. MacKey, I. 슬. Chen. Soc., 72, 6366 (1957)

(24) Lubby, W. P. and A. G. Sehrodt, 131d, 78, 1267 (1956)

(25) Ma, C., I. 뇨. Chen. See., 23, 1333 (1951)

(26) Mann, W. B., W. F. Marlowe, E. E. Hughes, R. M. Reese and V. H. Dibeler, Sofence, 133, 183 (1961)

(27) Muxart, R., Conpt. rend., 2/2, 2457 (1956)

(28) Muxart, R., Brul. Bec. chis. Prence, 1956, 1837

(29) Mer, A. O., Bhrs. Rey., 77, 789 (1950)

(30) Norr1s, L. and A. Snell, Nucleontes, 2, (3), 18 (1949)

(31) Packard Ina truneat Co., Lacrange, IIlinois

(32) Packard Ins trument Co., Cat. No. 6004061 , sp. act. $=5290 \mathrm{dpm} / \mathrm{mgm}$

(33) Peng, C., "Liquid Seintillation counting of Some Sulfur-35 Labeled Organie Compounds", in Lianid Selntiliation Counting, edited by C. G. Bell, Jx. and F. H. Hayes, Pergamon Press, Inc., New York, 1958. pp. 198-204.

(34) Rathburn, D. W., Kansas State Univeraity, unpublished results.

(35) Re1d, J. D. and H. D. Weithe, Ind. Eng. Chen., Anal. 르., 20, 27 (1938)

(36) Seitz, I. and J. S. Koohler, "Dlaplacement of Atom during Irradiation", Solid State Phrieses, Vol. II, edited by F. Selts and D. Turnbull, icademic Fress, Inc., New Iork, 1956. pp. 305-448.

(37) Shriner, R.L., R.C. Tuson and D.Y. Curtin, "The Systenatic Identifleation of Organic Compounds", 4th ed., John Wiley and Sons, Hew York, p. 202, 207.

(38) Sumner, J. B. and G.P. Somers, "Chemistry and Methods of Enzymes", 2nd ed., dead ende Press, Inc., New York, 1947. pp. 1544-160.

(39) The Merck Index, 7th ed., Merck and Co., Ino., Rahway, M. J., 1960 p. 642 .

(40) Tolbert, B. M., pheleonics, 18, (8), 74 (1960) 
(41) Dracerlab, Inc., Walthan, Mase., Lot I0. R-27, sp. act. $=2.22 \mathrm{nc} / \mathrm{gm}^{\mathrm{m}}$

(42) Whal, A. C. and H. A. Bonner, "Radioectivity Applied to Chomistry", John WIIey and Sons, New York, 1951. p. 263.

(43) Walhe, H. D. and P. B. Jacobe, Ind. Eng. Ghen., Innl. Ed., 8., 44 (1936)

(44) Weinberger, H., Ibid, 3, 363 (1931)

(45) W1llard, J., Inn. Reve. Fuez. Sef., 2, 2953 (1953)

(46) Wols, A. P., Int]. I. Anpl. Had. Inotopes, 2, 256 (1957)

(47) Wolf, A. P., Angey Chen., 2, 237 (1959)

(48) Wolf, A. P. and R. C. Anderson, I. An. Chen. Soc., II, 1608 (1955)

(49) Wole, A. P., B. Cordon, and R. C. Anderson, 1b1d, 78, 2657 (1956)

(50) Wolf, A. P., C. S. Redvanly and R. C. Anderson, 1bid, 72, 3717 (1957)

(51) Wolf, A. P. and B. Suryanararana, I. Ehrs. Chen, 62,1369 (1958)

(52) Wolf, A. P. and J. Y. Iang, I. 쏘. Cham. Soe., 82, 4488 (1960)

(53) Wolf, A. P. and J. Y. Yang, 1b1d, 82, 3315 (1960)

(54) Yankwieh, P. B., I. Chem. Phws., 15, 374 (1947)

(55) Jankwieh, P. E., Gan. I. Chen., 24, 301 (1956)

(56) Yankulch, P. B. and W. R. Cornman, Jr., I. 스. Ches. Soe., I7, 2096 (1955)

(57) Yankwleh, P. F. and W. R. Corman, Jr., 1bld, 78, 1560 (1956)

(58) Yankwlch, P. E., G. X. Rollefson and T. H. Norr 1s, I. Chem. Phys., I4, 131 (1946)

(59) Yankwich, P. E. and J. D. Vaughan, I. A‥ Chen. Soe., 76, 5851 (1954)

(60) zifferero, M., Ann. Chin., 药, 555(1954); C.4., 49, 5993 (1955)

(61) Zifferero, M., 1bid, 44, 563 (1954); L.A., 49, 5153 (1955)

(62) zifferero, M. and L. Ciers, 1b1d, 46, 105 (1956)

(63) zifferero, M. and I. Mas1, 1b1d, 노, 551 (1954); C..1., 49, 5992 (1955) 
THOMAS WILLIAM LAFP

B.A., Coe Colloge, 1959

Al ABSTRACT OF A MASTER 'S THESIS

submitted in partial fulfillwent of the

requirements for the degree

MASTER OF SCIMACE

Depertisent of Chemistry

KANSAS STATE UUIVRSITY

Nanhattan, Kansas

1961 
The chenical effects produced by the $\mathbb{1}^{1 / 4}(n, p) c^{\mathcal{H}_{4}}$ nuclear reaction on erystalline eyanoguanidine were studied after the plle-neutron Irradiation by dissolving the ample in vater and inveatigating the nature and relative anounts of the radiocarbon-labeled products.

Radioactivity neasurements were conviently made using liquid seint1llation counting techniques. A counting efficiency of $(50.0 \pm 1.4)$ par cent vas observed using a seintillator solution of FOFOP, PPO and naphthalene in p-dioxane. The effect of various solutes on the counting efficiency of the solnt1llator solution was studied. $\mathrm{N}, \mathrm{N}^{\prime}$-mothylphenyl thiourea and concentrated amonium hydroxide were found to produce marked deorease in the counting efficiency, whlle the addition of water had little effect on the counting efficlency.

The Inveatigation of the nature and relative anounte of the radiocarbonlabeled producta showed that littlo activity was present in the form of CO, $\mathrm{CO}_{2}, \mathrm{CH}_{4}, \mathrm{HCN}, \mathrm{CH}_{3} \mathrm{Cr}, \mathrm{HCHO}, \mathrm{BCOOH}$, urea and methylhydrasine. Mcetanidine, granidine, and a polymeric material, believed to be melanine, were found to contain 17, 13.5 and 13 per cent, respectively, of the totel induced activity. The parent compound, eyanoguanidine, was found to contain 41 per cent of the total activity induced In the ample by the neutron irradiation.

Possible wechanisms for the formation of eyanoguenidine, acetenidine, guanidine and melamine are suggested. Cyanemide, produced by the rragmentation of the cyanoguanidine malecule, is considered to pley an important role in the formation of the final products observed in solution. Interpretation of the observed results is made in term of the Selts-Roehler 
"displacement spike" model of the effects of irradiation on cryatalline materials.

The results observed in this study are compared to proviously reported results for the neutron Irradiation of nitrogen-contalning organic and Inorganic compounds in the solld state. 